
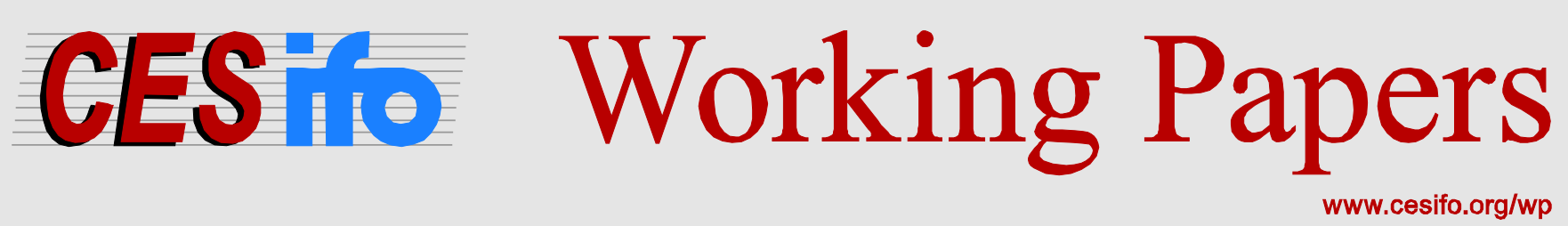

\title{
The Economics of Insurance, its Borders with Finance and Implications for Systemic Regulation
}

\author{
Christian Thimann \\ CESIFO WORKING PAPER NO. 5207 \\ CATEGORY 7: MONETARY POLICY AND INTERNATIONAL FINANCE \\ FEBRUARY 2015 \\ An electronic version of the paper may be downloaded \\ - from the SSRN website: \\ - from the RePEc website: \\ - from the CESifo website: \\ WWW.SSRN.com \\ www.RePEc.org \\ www.CESifo-group.org/wp
}

ISSN 2364-1428 


\title{
The Economics of Insurance, its Borders with Finance and Implications for Systemic Regulation
}

\begin{abstract}
Global financial regulators are currently reflecting on the nature of the insurance business. Specifically, they are trying to classify insurance into 'traditional' and 'non-traditional' activities, and to distinguish them from 'non-insurance' activities. Subsequently, they will seek to apply different regulatory treatments to these categories to achieve better control of systemic risk in the global financial system. This means that one of the most important current questions in international finance is 'what is insurance and where does insurance end?' This paper aims to elaborate on the economics of insurance and its borders with general finance. It argues that the classification challenge by regulators partly stems from terminological confusion between insurance activities and more general financial activities. Insurance and finance both use the same terms - in particular the ubiquitous notion of risk - but attach fundamentally different meanings to them. With the proper terminology at hand and a clear distinction between insurance products, product management activities and balance sheet management activities, the limits of insurance can be re-established. Such delineation is essential to determine appropriate systemic risk regulation.
\end{abstract}

JEL-Code: G000, G220, G280.

Keywords: insurance economics, finance, systemic risk.

$\begin{array}{cc} & \text { Christian Thimann } \\ \text { AXA Group } & \text { Paris School of Economics } \\ 25 \text { Avenue Matignon } & 48 \text { Boulevard Jourdan } \\ \text { France-75008 Paris } & \text { France-75014 Paris } \\ \text { christian.thimann@axa.com } & \text { christian.thimann@psemail.eu }\end{array}$

January 2015

Member of AXA's Group Executive Committee; Research Associate at the LSE's Systemic Risk Centre; and Associated Member at the Paris School of Economics. The paper has benefitted from substantive comments by Henri de Castries, Denis Duverne, Alban de Mailly Nesle, Amélie de Montchalin, Quentin Gisserot, Fabrice Lorillon and Pierre-Charles Pradier, as well as from discussions on the subject with Don Kohn. Views expressed are those of the author. 


\section{Introduction}

What is insurance, where does insurance end and general finance begin? What sounds a simple, perhaps even awkward, question is one of the most important issues in global finance at present. The reason is that financial regulators broadly agree that most activities conducted by insurance companies do not pose a systemic risk in the financial system, but that certain activities might do so. In general, activities concerning property and casualty insurance, health insurance and most parts of life insurance fall into the first category. But there are certain specific life insurance products, as well as advanced techniques of financial and risk management, which are viewed with some concern, especially when conducted by large firms.

Regulators clearly have in mind the case of AIG, the US insurance company that triggered the largest bailout in US history because the non-insurance activities of its financial branch were judged as highly systemic, implying that a collapse of AIG would have severely damaged the financial system and hurt the real economy. Regulators have labelled activities with potential risks as 'non-traditional' insurance activities. They have not yet agreed on which precise activities should be classified in this category, but they have tentatively allocated specific life insurance products as well as several financial operations and tools into it, and they are considering the application of capital surcharges to such activities.

This would be a far-reaching decision with important implications not only for the systemically important insurance companies concerned but also for the whole insurance industry because many of these activities are conducted across the sector. Therefore, the crucial question is whether it is possible to distinguish 'traditional' from 'non-traditional' activities and, more generally, where insurance activities end and 'non-insurance activities' begin?

Capital surcharges would add a third layer of regulatory response to the systemic role of insurance:

- The first layer has been to establish supervision at the level of the insurance group rather than at the level of individual entities. The latter was the case for AIG and this de facto left some activities unsupervised.

- The second layer concerns the preparation of detailed risk management plans. These outline potential risks and help to manage them in the event of risk materialisation.

- The third layer, currently under discussion, would consist of capital surcharges for certain companies and/or activities. It would mean that companies would have to raise more capital, dilute ownership, lower the return on equity and potentially become less attractive to investors - unless these non-traditional non-insurance activities are particularly profitable - in which case the equation could stay positive.

From a public policy perspective, capital surcharges represent severe regulatory interventions that need to be thoroughly justified, particularly in view of their potentially distortive effects. Such justification starts with answering the first of the OECD's ten-point list on regulation: 'what is the problem?' (OECD, 1995). Specifically, applied to the issue under consideration in this paper, the question becomes: 'what is the problem with certain activities undertaken by insurance companies with regard to potential systemic risk'?

For banks, the identification of systemic activities is relatively straightforward: banks create and handle money, whose value and economic function rests on the trust that agents have in the currency. As banks can create money, they can affect that trust - which can have 
immediate systemic consequences. Moreover, by the very nature of their business, banks operate in a system: the banking system, with the central bank at its centre. In this system, banks are institutionally interconnected through the interbank market and their access to central bank operations; their liabilities constitute the means of payment in the economic system; and they are jointly accountable for the stability of deposits as well as the operation of the payment system. Banks can fulfil their statutory functions only as part of a system (Thimann, 2014).

In such a set-up, contagion is prevalent, and shocks quickly affect the system as a whole. Therefore, in the case of banking, the majority of activities - deposit holding, interbank lending and liquidity management, as well as money and credit creation - are inherently systemic. The stability of individual banks is closely linked to the state of the financial system, as external liquidity is permanently needed, and it is largely a question of size as to what degree banks pose significant risk to the system. The larger the bank, the bigger the systemic risk it poses. As a logical consequence, capital surcharges are applied to the largest banks and cover all their activities.

For insurance, the identification of activities with potential systemic risk is much less straightforward. The very elements that make banks systemic do not apply to insurance companies: there is no lending and borrowing among them as in the interbank market; there is no 'central insurer'; and the existence of reinsurers adds a backstop, absorbing and mitigating risk through diversification ${ }^{2}$ (IAIS, 2012). Moreover, insurance companies do not create money or credit and their liabilities do not constitute a means of payments. They are standalone operators, linked with the financial system essentially through their role as financial intermediaries and financial investors. In many ways, insurance companies are more comparable to asset managers than to banks.

Therefore, the question of why and to what extent insurance activities can be systemically important is difficult to address, and to date, it has not received a satisfactory answer. The classification proposed by regulators of 'traditional' and 'non-traditional' insurance activities has semantic appeal, but due to innovation in insurance products - inter alia, in response to changes in public policies in the areas of pension or health, or in response to policyholder demands and financial innovation - such a distinction does not follow naturally from business conduct. Regulators themselves have so far not provided a rigorous rationalisation of such classification and even the various classifications that were provided are not all consistent.

This paper provides an analysis of the economics of insurance activities in the light of systemic risk regulation. Section II begins by recalling the essence of insurance and distinguishes it from other financial activities, based on a clarification of key concepts, particularly risk, value and loss. Section III provides a conceptual framework for a better understanding of ('traditional') insurance activities, describing various economic concepts both in terms of risk transfer and business models. Section IV provides an attempt to classify insurance activities and tools based on business purpose and functions rather than chronology. Section V discusses the implications for regulation. Section VI concludes.

\footnotetext{
2 'Traditional reinsurance - including the reinsurance of peak risks - is unlikely to contribute to, or amplify, systemic risk. While reinsurance establishes intra-sector connectivity, the hierarchical structure of the insurance market dampens the propagation of shocks through the insurance market. Although reinsurers can fail, in the past, primary insurers have typically absorbed the loss of reinsurance recoverables without a significant detrimental financial impact', Reinsurance and Financial Stability, IAIS, July 2012
} 


\section{The economics of insurance}

What are the economics of insurance, how does insurance differ from general finance and what is its deeper purpose? This section elaborates on these questions, describes why and how insurance is regulated and discusses the AIG failure in this context.

\section{a. Insurance versus finance}

Insurance is the business of accepting insurable risks, managing them and providing compensation for possible losses. This statement describes insurance with three qualifications: $^{3}$

i. Insurable risks are faced by policyholders but beyond their control; they are not systematic but subject to the law of large numbers; and they are non-financial - that is, not directly related to the economic and financial cycle. ${ }^{4}$

ii. The managing of risk takes place through pooling or mutualisation - that is, the aggregation of a large number of similar risks, linking the misfortune of the few to the fortune of the many; or it takes place through cession and diversification, which are the other ways to manage insurance risk. ${ }^{5}$

iii. Compensation takes place for losses that have actually occurred, not for hypothetical losses nor for events that may have caused losses.

Insurance and its basic concepts pre-date modern economic theory and especially finance. But its key notions - especially that of risk - have been espoused by the economics profession from the 1920s onwards. They were transformed and popularised in particular by the development of financial economics in the 1950s and 1960s, and today they are omnipresent in economics, corporate finance and even the everyday media commentary about financial markets. In this process, the notions that were longstanding insurance concepts received a very different meaning.

The concept of risk started to be used outside the boundaries of insurance in the early parts of the twentieth century. Frank Knight brought it forcefully into modern economics through his 1921 treatise Risk, Uncertainty and Profit. The concept of risk was popularised through modern portfolio theory, which is based on a rational investor who seeks to optimise return for a given level of risk or to reduce risk for a targeted level of return. These ideas and related models have been firmly established in financial economics through the work of Markowitz (1952 and 1957), Lintner (1965) and Sharpe (1963 and 1964). Their work led to the capital asset pricing model, which describes the relationship between risk and expected return, and serves as a benchmark for the pricing of securities.

In the 1980s, the mixing of finance and insurance became even more intricate with a new strand of literature and market offer on 'portfolio insurance', which arguably could be obtained through combining the reference portfolio with riskless assets and various options (Leland and Rubinstein, 1976; and Leland, 1980). At that point, the literature had not only taken up the key terms of insurance into a new field but actually started to use the label of insurance itself - the confusion arising from this process has lasted until today.

\footnotetext{
${ }^{3}$ Among the insurable risks, not every insurance company covers all risks; depending on their business line they may choose the types of risk they cover.

${ }^{4}$ Insurance companies can, however, themselves be exposed to financial risks, for example, when they provide guarantees on capital or interest rates in a wide range of life insurance contracts. The hedging of those risks is the main reason why insurance companies need derivatives.

${ }^{5}$ For example, insurers can use reinsurance or hedging to eliminate the risk.
} 
Unsurprisingly, the notion of risk is now omnipresent in this literature: risky assets, risk-free assets, risk-return trade-off, asset-specific risk and market risk, risk profile, risk tolerance and risk reduction strategies, to name but a few, and the same holds true for the notions of values and losses.

It is therefore important to clarify the key concepts of insurance and contrast them with their meaning in finance.

In insurance, key terms include:

- Risk is the possibility of actual damage, injury, liability or loss of existing value or status (property, health, life) as a consequence of an external event.

- Value refers to an actual endowment regarding property, health or life.

- Losses refer to the partial or total damage of the object insured or personal injury experienced by the policyholder.

- Trading of insurance contracts is generally not possible; ${ }^{6}$ an insurance company may cede some of the risk taken to a reinsurer or the financial market, for example, via socalled Natcat bonds, ${ }^{7}$ but itself remains fully liable vis-à-vis the initial policyholder. ${ }^{8}$

In finance, and specifically capital markets, these terms have a fundamentally different meaning:

- Risk means uncertainty or probabilistic change ${ }^{9}$ in value over time. A financial asset is considered risky when the standard deviation of its fluctuations over time is positive and/or when its return is not guaranteed ${ }^{10}$; the higher the standard deviation and the larger the possibility that the actual return is below the expected return, the riskier is an asset. ${ }^{11}$

- Value is the price of an asset or a portfolio at a given point in time. In principle, when prices follow a random walk or a random walk with a drift (Fama, 1965; Malkiel, 1973; Lo et all., 1999), the value of a financial asset is bounded from below at zero and it is unbounded from above.

- Losses are a negative change in the asset value over a given period.

- Trading refers to the exchange of contracts at varying prices, and is generally possible.

\footnotetext{
${ }^{6}$ An exception is the U.S. where some life insurance contracts are tradeable in principle; here, there are policy holders who sold their life insurance contracts, mostly to investment companies, when faced with a critical illness and in need of cash.

${ }^{7}$ Natcat bonds are risk-linked securities that transfer a specified risk from an insurance company to investors. Such securities are a way to alleviate some of the risk that insurance companies take, especially in the context of natural catastrophes. Average issuances in recent years were below \$5 billion, covering a small fraction of the insurance market.

${ }^{8}$ The difference in trading and tradability between insurance and finance contracts is yet one more argument making the marking-to-market of the full balance sheet of insurance companies compared to the partial markingto-market of the balance sheet of banks (only the trading book that is typically a fraction of the balance sheet) more problematic. It is ironic that banks only have to mark-to-market their limited trading book, whereas insurers have to mark-to-market their full balance sheet even though insurance contracts are generally not tradeable. This issue would warrant a separate paper.

${ }^{9}$ Knight (1921) introduced the distinction between probabilistic change and changes where the probability distribution of outcomes was unknown; such distinction is however not essential here.

${ }^{10}$ The corporate finance literature often distinguishes between "pure risk", which only refers to possible losses, and "speculative risk", which can involve both a possibility of gain or loss (Merna et al., 2008). In this terminology, only pure risks are insurable.

${ }^{11}$ Accordingly, equities are typically seen as riskier than corporate bonds, which are typically seen as riskier than government bonds, which are seen as riskier for some countries than for others.
} 
It is essential to clarify the fundamental distinction between risk in insurance and risk in finance. Risk materialisation in insurance is a relatively rare event, happening exogenously 'out of normal'; by contrast, in a market economy or finance, risk materialisation is endogenous, 'within normal', and happens all the time. Values in insurance are based on actual values, whereas value in financial markets refers to expected value. And losses in insurance are actual losses related to damage or injury, whereas losses in financial products reflect decreases in value, including to zero.

Consider these points in more detail: property and casualty insurance, health insurance and life insurance exist because the threats to these values are relatively rare, 'out of normal' events and warrant protection. Specifically, property exists to serve its owners; thefts or destructions through fire or flood are events 'out of normal', and owners can therefore purchase property insurance against their consequences. Cars are made to ensure mobility, not to have crashes; owners can therefore buy insurance against the consequences of an accident. Life is made to last, not to end from accidents or disease at a young age; people can therefore buy insurance against the consequences of 'life accidents'.

Table 1. Key concepts in insurance and finance compared

\begin{tabular}{|c|c|c|}
\hline Insurance & & Finance \\
\hline $\begin{array}{l}\text { Possibility of actual damage, injury, } \\
\text { liability or loss }\end{array}$ & Risk & Uncertainty in value over time \\
\hline $\begin{array}{l}\text { Relatively rare occurrence, happening } \\
\text { 'out of normal', as a consequence of } \\
\text { an external event }\end{array}$ & Risk materalisation & $\begin{array}{l}\text { Inherent feature 'within normal', } \\
\text { happening continuously }\end{array}$ \\
\hline $\begin{array}{l}\text { Actual endowment regarding property, } \\
\text { health or life }\end{array}$ & Value & $\begin{array}{l}\text { Price of an asset or a portfolio at } \\
\text { a given point in time }\end{array}$ \\
\hline $\begin{array}{l}\text { Partial or total damage of the object } \\
\text { insured or personal injury experienced }\end{array}$ & Loss & Negative change in asset value \\
\hline $\begin{array}{l}\text { Possible only if an exposure to the risk } \\
\text { exists }\end{array}$ & Purchase of protection & $\begin{array}{l}\text { Possible also if no exposure to } \\
\text { the risk exists }\end{array}$ \\
\hline Damage & Trigger for payouts & Event \\
\hline Determined by actual damage & Compensation level & Determined by product terms \\
\hline Case-by-case & Compensation differentiation & Same for all instrument holders \\
\hline $\begin{array}{l}\text { No. Insurance cannot create profits for } \\
\text { policyholders (except for life insurance } \\
\text { products); loss compensations cover at } \\
\text { best the loss in full }\end{array}$ & Profits possible? & $\begin{array}{l}\text { Yes. Profits are possible; } \\
\text { payouts can exceed a possible } \\
\text { loss from event and even occur } \\
\text { if there is no loss }\end{array}$ \\
\hline Generally not possible & Tradability of contracts & Generally possible \\
\hline
\end{tabular}

Source: Author's compilation. For further explanations see text. 
In contrast, fluctuations in asset values leading to temporary or permanent price declines or 'losses' in value are 'within normal' and happen all the time in capital markets; they lie within the nature of financial markets, it is not possible to purchase insurance against such losses. The permanent adjustment of prices over time is an intrinsic feature of financial markets, whose main function is to incorporate all relevant incoming information. Even complete losses in the value of assets are within the range of market outcomes and lie in the nature of a market economy. Arrangements that offer protection against such events 'within normal' are not insurance products but financial products.

Life insurance contracts with a savings component are closer to finance than pure risk life insurance products or property and casualty insurance products. In life insurance products with a savings component, the insurance companies often provide a guarantee of the paid-in capital (e.g. in France and many other countries) and/or a guaranteed minimum return (e.g. in Germany, where the guaranteed rate of return is currently $1.25 \%$ per year). The insurance company providing such guarantees exposes itself to financial risks and it needs to use derivatives to hedge such risk.

How do such contracts fit into the scheme outlined above? The purpose of such contracts is to provide the policy holders with a protection against the risk of longevity through life-long annuities or with a protection of the survivors in case of death. These are insurance risks, they are not risks related to the financial cycle. The financial guarantees are attached to such contracts in order to make the protection meaningful. And as a result of these guarantees, it is the insurance company that is exposed to financial risks, for example in case asset markets or market interest rates decline. Such contracts are nevertheless insurance contracts because the risk of the policy holder is an insurance risk; the exposure to the financial cycle is not between the policy holder and financial markets but between the insurance company and financial markets. Insurance and finance come closer in the case of life-insurance products with financial guarantees, but the nature of the relationship between the policy holder and the company remains of an insurance-type, and it is the company that is exposed to, and has to manage, the financial risk - through pooling, diversification, hedging, or cession.

\section{The case of $C D S$}

Among the many financial products that are most confused with insurance contracts are those leading to accepting credit risk such as credit insurance, financial guarantees and credit default swaps (CDS), because they are often regarded as an insurance against the possible default of an issuer. CDS are mostly issued by banks ${ }^{12}$ and sold to a very large range of investors. Investors can and do buy these contracts independent of whether they have an exposure to the issuer concerned or not. CDS are issued separately from the bonds by the issuer concerned and buyers receive a payout in case of default (or wider adverse 'credit events'), independently of whether they experience a loss from default or not.

Are CDS insurance contracts? No, they are not, for two main reasons: first, because the default of a counterparty is an inherent feature in a market economy ${ }^{13}$ and second, because CDS payouts are not damage-driven but event-driven. There are several further attributes that show how far such contracts are from being insurance: CDS contracts are created and sold independently of whether buyers would actually suffer a damage in case of default; they can

\footnotetext{
${ }^{12}$ In practical terms, five large banking (not insurance) corporations dominate the CDS space and issue over 90\% of contracts worldwide: Morgan Stanley, Bank of America Merrill Lynch, Goldman Sachs, BNP Paribas and Deutsche Bank. The total value outstanding is estimated at \$20 trillion as of end June 2014 (BIS, 2014).

${ }^{13}$ The financial sector even created rating agencies to estimate this 'normal feature' of default as part of market functioning.
} 
be produced in unbound numbers and their value can far exceed the value of the underlying assets outstanding; they are determined by a market committee assessing debtor behaviour rather an insurance expert assessing creditor impact; ${ }^{14}$ they are freely tradable and they can generate profits. It is for all these reasons that large-scale naked CDS selling creates systemic risk in the financial system.

In sum, these considerations illustrate that insurance companies serve to absorb risk ${ }^{15}$, whereas financial products spread risk: in insurance, for a given risk, there is a finite number of contracts with a given upper value that can be sold (for example, the number and value of cars in a region) and, assuming full coverage, the population is no longer exposed to the consequences of the risk materialising. In contrast, there is no limit to the number or value of CDS contracts that can be sold for a given risk and the population can be more exposed (positively in case of gain or negatively in case of loss) than before ${ }^{16}$. And financial contracts are generally tradable and allow profit-making, whereas insurance contracts do not.

\section{b. Why and how insurance is regulated}

The insurance business is regulated essentially for three reasons: first, there is an overarching public interest in the smooth provision of insurance services to the economy and society at large because insurance contributes to the economic security and protection of households, firms and communities. ${ }^{17}$ Insurance also allows individuals and firms to develop their talents and business despite the presence of risk, which is an essential condition for economic development and growth.

Second, insurance contracts are typically long-term relationships, providing the desired protection only when the long-term survival of the insurance company is ensured. So regulation should ensure the long-term existence of insurance companies. This also relates to the fact that insurance companies are typically paid long before they deliver. In many insurance segments, the time lag between payment and delivery can extend to decades. ${ }^{18}$ This

\footnotetext{
${ }^{14}$ The decision whether or not a default occurred and CDS payments need to be made is usually determined by the Determinations Committee of the International Swaps and Derivatives Association, comprising a predetermined set of financial market participants (usually dealers) as members.

${ }^{15}$ Parametric insurance contracts are an interesting example of sophistication in insurance, which nonetheless respect its main features. Contracts continue to make explicit the precise conditions that will lead to compensations - as a car insurance contract would state under which conditions (its nature, intensity and cause) a material damage will be (partly or fully) paid by the insurance company. Parametric insurance contracts are innovative in the sense that they relate to situations damage is not directly observable, and estimated ex ante by a number of proxies taking the form of observable external parameters (not market conditions and not 'events' defined by an external commission as in the case of CDS). No profits are possible for policyholders and compensation is designed to increase according to the intensity of the damage. Examples include insurance against low snow levels for ski resort companies; or against droughts in specific regions for farmers.

16 „When Lehman Brothers defaulted in September 2008, it had $\$ 155$ billion in outstanding debt, yet $\$ 440$ billion of CDS referencing this debt had been sold“ (Geneva Association, 2010).

${ }^{17}$ As many parts of life and health insurance are closely related to the public social security systems, there is an additional proximity between public systems and private insurance providers. Changes in one of these two sectors can have direct implications for the other.

${ }^{18}$ The time lag also gives insurance a peculiar economic feature between services, where production and consumption necessarily coincide (for example, provision of advisory services), and goods, where production and consumption can be disconnected over time. This may be one of the reasons that insurance until some decades ago was not classified within the financial sector but within industry, and it only in the System of National Accounts of 1993 that insurance companies were put in a new major sector of financial corporations (See the System of National Accounts 1993 - 1993 SNA from the United Nations Statistics Division).
} 
means that insurance companies have to be credible in being able to honour their commitments far after they take them on.

And third, even though insurance is established through bilateral contacts with individual policyholders, the soundness of any single contractual relationship can only be assessed jointly with the management of other contracts. As risks are pooled and mutualised, a collective assessment needs to be undertaken. By the same token, to oversee the soundness of individual contracts, the regulator cannot act merely on the basis of individual contract law, but needs powers to address the collective management of risk.

Hence, both the time dimension and the cross-section dimension of insurance services are crucial for regulation. Policyholders cannot assess by themselves the quality of management at any point in time nor over time due to lack of information or disproportionate information costs, or lack of expertise and authority over the insurance provider. It is to incorporate such considerations that oversight is bestowed on the public regulatory authority (Stigler, 1971; Peltzman, 1976).

Functionally, regulation involves licensing insurance companies; authorising and regulating insurance policies and products; ensuring the financial soundness of insurance companies; monitoring governance and risk management methods; and controlling market practices. As this list shows, the current debate on 'systemic risk' is entirely new for insurance regulators.

\section{c. The consequences of non-regulation: the AIG failure}

AIG is the alpha and omega of systemic risk regulation. Its emergency rescue required the injection of $\$ 180$ billion of public funds equivalent to the net worth of 1.8 million households, ${ }^{19}$ with the supervisor not being aware, let alone understanding its activities. ${ }^{20}$

AIG failed in September 2008 due to a liquidity crisis triggered by its multiple exposures to the US subprime mortgage crisis. The main cause of the liquidity shortage was the significant CDS activity run by, it is told, ten staff members within AIG's Financial Products Division in London. This subsidiary was virtually non-regulated and effectively non-supervised. According to the US government commission, the Office of Thrift Supervision 'failed to effectively exercise its authority over AIG and its affiliates: it lacked the capability to supervise an institution of the size and complexity of AIG, did not recognise the risks inherent in AIG's sales of CDS, and did not understand its responsibility to oversee the entire company, including AIG Financial Products. ${ }^{, 21}$

Given that an important amount of these CDS were on residential mortgage-backed securities (RMBS), AIG was faced with increasing demands from counterparties for collateral when the value of the securities plummeted due to subprime exposure, thus draining the holding's liquidity. Independently, AIG encountered problems with the aggressive securities lending programme run by its insurance subsidiaries. Because the subsidiaries had invested large amounts of the cash collateral received from borrowers on RMBS, the holding had to provide

\footnotetext{
19 The average net worth of the median household in the United States is about $\$ 100,000$ (source: Federal Reserve Bulletin, Sept 2014).

${ }^{20}$ Other than AIG, very few insurance companies came under pressure in the crisis. In the United States Hartford and Lincoln National required government support, but for less than 2\% of the amount for AIG; in Europe, insurance companies required support of less than EUR [10] billion, compared with EUR 580 billion of state aid for banks (source: European Commission).

${ }^{21}$ US government 'Inquiry into the Financial Crisis Report' 2011.
} 
assistance when the securities lost their value. This aggravated the liquidity crisis AIG faced, but also endangered the solvency of several of AIG's insurance subsidiaries.

AIG was consequently downgraded by credit rating agencies and became unable to find the liquidities to match the increasing calls for collateral against the CDS and the securities lent, and was consequently bailed out on 15 September 2008.

Researchers and public authorities generally agree that the losses incurred because of the securities lending activities and RMBS investments. These alone may well have triggered the failure of several of its regulated insurance subsidiaries, but could not have toppled the AIG group without the CDS troubles. It was the subsidiary that used AIG's solid rating from the insurance part 'to run a huge casino that then overwhelmed the entire business' (Sorkin, 2009). Or as Edward Liddy, who became AIG's chief executive after the bailout, noted: 'It's a structure where you have an insurance company that works really well and on top of it there is a holding company and the holding company's biggest asset is this huge hedge fund.' This is yet another confirmation of the AIG debacle being due to (unregulated) financial risk-taking, not to insurance risk-taking.

\section{Conceptual approaches to ('traditional') insurance}

This section tests different conceptual approaches to the question 'what is insurance', especially the notions of 'traditional' and 'non-traditional' insurance.

\section{a. Tautological definition}

Inspired by the well-known tautological definition of money - 'money is what money does' (Spindt, 1985) - it might be tempting to say 'insurance is what insurers do'. But for obvious reasons, such a definition is entirely unsatisfactory; it is also utterly inappropriate as all regulatory texts specify insurance activities in great detail. For example, the EU Directive on Solvency II of December 2009 defines the various activities of life and non-life insurance activities. They refer to provision of assurance on survival to a stipulated age, death, annuities, supplementary insurance, and insurance against personal injury, incapacity for employment, accident or sickness as well as a two-page list of non-life activities. ${ }^{22}$

Hence, nobody self-declares as an insurer or self-declares an insurance product; such approval takes place by public authorities. An appropriate rephrasing of the above definition might therefore be 'insurance is what regulators allow insurers to do' - and so far regulators have allowed insurance companies to engage in the 'non-traditional' and 'non-insurance' activities that are currently under scrutiny.

In the context of systemic risk regulation, a tautological definition would imply that everything is systemic or nothing is systemic. Neither of the two options are credible; the second one is not credible due to the activities undertaken by AIG that were clearly systemic, even though they were non-insurance activities.

\footnotetext{
${ }^{22}$ Annex I provides under $\S 14$ also 'Credit insurance' against 'insolvency (general), export credit, instalment credit, mortgages, agricultural credit' (to be seen against what was said on financial insurance).
} 


\section{b. Chronological definition}

\section{i. General insurance activities}

'Traditional' and 'non-traditional' are the terms used by global regulators to delineate insurance products. Such notions clearly evoke a time dimension, given that traditions are behaviours established over time. Insurance is as old as mankind, but when were traditions established?

There are reports about insurance against transport losses among traders in China $3000 \mathrm{BC}$ (Vaughan, 1997); about commercial insurance through conditional loans in Babylon 2000 BC (Trenerry, 1926); and about health and life insurance through organised guilds in ancient Greece and the Roman empire (Holdsworth, 1917).

Modern insurance is usually traced back to the period of enlightenment in the seventeenth century. Property insurance as we know it today is usually traced to the Great Fire of London in 1666 , after which the first fire insurance company was established. ${ }^{23}$

Commercial insurance in its modern form was developed around the same time. In $1688,{ }^{24}$ Edward Lloyd opened a meeting facility for parties seeking insurance of ships and cargoes and those willing to underwrite such risks. These informal beginnings led to the establishment of the insurance market 'Lloyd's of London', which eventually became the Society of Lloyd's.

Life insurance developed in London around the same time. The first company to offer life insurance was the Amicable Society for a Perpetual Assurance Office, founded in London in 1706 and starting with 2,000 members. Half a century later, the necessary mathematical and statistical tools were in place for the development of life insurance as it is known today. In 1762, the world's first mutual insurer that used age-based premiums and estimated mortality rates was established: Equitable Life laid the framework on which virtually all life insurance schemes were subsequently based. ${ }^{25}$ Is this 'traditional' insurance and all that comes later 'non-traditional'?

\section{ii. Derivatives}

Those who conjecture that derivatives are new and therefore by definition 'non-traditional' may be reminded of the Old Testament, where in Genesis (29: 15-20), usually dated 1700 BC, Jacob acquired through seven years of labour an option to marry Laban's daughter Rachel. But his prospective father-in-law reneged (an early default) and Jacob had to purchase another option, requiring more labour, finally to marry Rachel.

Closer to modern times and closer to the formal finance definition of a derivative as a 'security the price of which is dependent on one or more underlying assets', derivatives started playing an increasingly important role from the seventeenth century onwards. They were an important driver of the famous Dutch tulip mania of 1637, when they allowed traders to conduct trade in tulips all year round, and at the same time the first 'futures' contracts were established in the rice market in Osaka around 1650, where they enabled rice traders to purchase rice for resale or future consumption at a prearranged price without having to worry about storing the rice in the meantime (Moss, 2010).

\footnotetext{
${ }^{23}$ But there are proofs of mutual fire insurance of houses in Hamburg already from 1591 (Evans, 1987)

${ }^{24} \mathrm{http}: / /$ www.lloyds.com/lloyds/about-us/history

${ }^{25} \mathrm{Cf}$. Archive of the Equitable Life Insurance Society.
} 
It was during the same period when research on derivatives began. The path-breaking analysis of 'modern' financial markets by the Spaniard José Penso de la Vega of 1688, which is still seen as among the best finance books of all time ${ }^{26}$, discusses stock market functioning, including options, futures and speculation, and bears the revelatory title 'Confusion de Confusiones'(Levine, 1996).

Markets for derivatives were institutionalised through the creation of the Chicago Board of Trade in 1848 and the Chicago Mercantile Exchange in 1919. In 1922, the US federal government made its first effort to regulate the futures market; and in 1955, the Supreme Court ruled that profits from hedging are to be treated as ordinary income. In 1972, the Chicago Mercantile Exchange allowed trading in currency futures, responding to the floating of currencies; in 1975, the first pure interest rate future based on Treasury bills followed; and in 1982, the Eurodollar contract was created, which is now the most actively traded of all futures contracts. Stock index futures were created around the same time.

Again, in view of this continuous historic development since at least the seventeenth century, can today's use of derivatives be seen as 'non-traditional'? (Chance, 1995)

\section{iii. Variable annuities}

The most prominent item on regulators' lists of potential systemic risk in insurance are socalled variable annuities. Variable annuities were invented in the United States in 1950. Until then, insurance companies only sold fixed-income annuities. To provide an appealing value proposition at a time of higher inflation rates, William C. Greenough of the Teachers Insurance and Annuity Association (TIAA), developed the idea to invest in 'units' of common equity, rather than 'dollars' of fixed income, and thereby to receive a pension with a variable payment stream, depending on market developments. The revolutionary idea underlying this proposition was that variable annuities are valued in terms of their underlying assets rather than their liabilities, as in a variable annuity, by definition, the assets always equal the liabilities.

These variable annuity contracts were provided by the newly founded College Retirement Equities Fund (CREF), which is now the world's largest issuer of variable annuities in a gigantic market amounting to almost $10 \%$ of US GDP. The fact that the world's largest issuer of variable annuities, TIAA-CREF, is not designated as systemically important by either US or global insurance regulators proves that variable annuities as such should give no cause for concern.

The concern only refers to variable annuities with so-called secondary guarantees. Such guarantees started being offered in the 1990s and provide policyholders with minimum guaranteed benefits. This structure implies that in rising market conditions, policyholders benefit from market upswings, and in market downswings can draw on the guarantees. In economic terms, this means that policyholders have a put option that they can exercise when the market declines. The strike of this put option equals the maximum value reached of the underlying asset, in this case the value of the guarantee. Obviously, the exercise of such options exposes the insurance provider to substantial risk in a market downswing.

To hedge itself against such risk as much as possible, the insurance company purchases swaps and forwards so that it makes no losses if policyholders exercise their options. More

\footnotetext{
${ }^{26}$ The Financial Times classified this book among the ten best books of finance and investment ever written.
} 
specifically, the insurance company is exposed to two types of risks: market risk and policyholder behaviour. ${ }^{27}$

This is why the variable annuity business with secondary guarantee is seen as risky within the financial system and why it is associated with a heavy use of derivatives, which in turn are seen as either risky or a source of (worrisome) interconnectedness. This is the heart of the matter of variable annuities with regard to systemic risk.

As we see from the above considerations, a chronological definition into 'traditional' and 'non-traditional' insurance activities does not carry the discussion much further. The issue must be explored on a product-by-product basis, with an assessment of possible sources and transmission channels of systemic risk.

\section{c. Risk transfer as a definition of insurance?}

The third definition of insurance that is often discussed is that insurance occurs when ever a risk transfer takes place. Most economists agree that 'AIG was not insurance' (Baranoff, 2012, and Henderson, 2009), but some consider that AIG was insurance 'because a risk transfer took place' through the products AIG sold.

The sections above have already provided a substantive explanation of why the AIG debacle is not insurance, namely because these activities were beyond the scope of insurance properly defined and because CDS are a financial contract and not an insurance contract. The difference between CDS and insurance contracts can be seen also for credit insurance, as undertaken for example by Euler-Hermes in Germany or Coface in France: the latter will only insure actual defaults of debtors (or trade credit obligations), can be purchased only by holders of actual claims and serves to absorb potential losses; by contrast, for CDS the nominal amount may be infinite, anyone can purchase such 'protection' even though not exposed and profits are well possible.

In general, a 'risk transfer' does occur in insurance contracts, but not all that is a risk transfer is insurance; a risk transfer is a necessary element in insurance but it is not sufficient to define insurance as such. First, the nature of risk being transferred must be of insurance type, not of financial type, as defined above. The risk transferred in the AIG business violates all of the insurability assumptions: AIG was assuming risks that policyholders were not actually exposed to; it could not be pooled and mutualised subject to the law of large numbers; and it was not unrelated to the economic and financial cycle.

Interestingly, many risk-transfers are undertaken in a context where no one would claim this is insurance in the sense that regulators understand it. In addition to the range of insurance products available - liability, property, business interruption - some large firms do, for example, run their own 'captive insurance' companies to distribute risks across their own different operations and subsidiaries (WEF, 2014). They are not regulated as insurance companies when doing so, as the risk is seen as staying in the same group and as mutualisation and pooling are only partial and without consequences for external actors. More widely, new non-insurance, risk-transfer markets are being created on some specific types of risks ('Alternative Risk Transfer' may, for example, refer to CatBonds, intellectual property insurance...).

\footnotetext{
${ }^{27}$ More precisely, market risk can arise in (only) three cases: basis risk, i.e. divergence between the asset and the hedging instrument; high volatility which raises the cost of hedging above the price of the guarantee; and market disruption, which makes hedging temporarily impossible.
} 


\section{d. A business model approach}

The most promising route for defining 'genuine' insurance activities is to start from their economic function. As mentioned above, insurance exists to provide protection against adverse events by linking the misfortune of the few to the fortune of the many. The object of protection may change over time; well-established objects such as property, health, old-age income and life may remain, and new objects such as cyber-safety or reputation can come on top.

The way in which protection is provided may also change over time because policyholder demands evolve and the macroeconomic and policy environment changes. Innovation in information technologies may allow for more tailor-made solutions and more refined pricing. Changes in the policy environment, such as macroeconomic developments or changes in social security systems and taxation, may also contribute to the evolution of the way insurance is provided.

Finally, the way in which insurance contracts are managed may evolve over time as new financial products that can serve insurance companies are developed and as regulation changes. The introduction of regulation based on economic risks, mark-to-market accounting and quarterly market reporting may well affect the way in which insurance contracts are managed.

Innovation in objects, products and tools means that the distinction between 'traditional' and 'non-traditional' is very difficult to make operational. It would be more operational to distinguish between insurance and non-insurance. The former has to start from the economic purpose and then consider whether the products under consideration are serving the purpose and whether the tools are necessary or helpful to manage the products.

These considerations are pursued in the subsequent section.

\section{The conundrum of 'traditional' and 'non-traditional' activities}

\section{a. Classifications proposed by regulators}

For many years, regulators have attempted to classify certain insurance activities as 'nontraditional non-insurance' (NTNI) ${ }^{28}$. But these attempts have not led to a robust view of these categories; rather, they have produced contradictions and overlaps. Even years after the first compilations of these lists, the European Commission acknowledges: 'There is no clear-cut definition of traditional insurance business' (European Commission Consultation Paper, 2012).

A number of items on the various NTNI lists, where in total over 20 items can be found, are recurrent: 'Non-traditional' activities often include variable annuities, mortgage guarantee insurance, trade credit insurance, financial guarantee insurance, derivatives, securities lending and repos. 'Non-insurance' activities often contain asset management and banking activities, as well as CDS/CDO underwriting and industrial activities (Table 2).

\footnotetext{
${ }^{28}$ There are four main sources: the Insurance Financial Stability Report of November 2011, the Assessment methodology of July 2013, the Report on 'Policy measures for systemically important insurers' of the same month, and the formula for the Basic Capital Requirement of September 2014.
} 
The classification has fluctuated over time, as examples show (see Annex Table 1):

- Variable annuities with living benefits or death benefits, commercial credit insurance and mortgage guarantee insurance were classified as 'semi-traditional' by the IAIS in 2011 and as 'non-traditional' thereafter.

- Callable life insurance products were classified as NTNI twice and the other two times not mentioned at all.

- Securities lending was classified 'traditional' in 2011 and as 'non-traditional' in the first report of July 2013. In the second report of July 2013, it was classified as ' 'traditional' if cash collateral is invested in liquid assets and as 'non-traditional' otherwise'.

- Repos were not mentioned in 2011, but they classified 'non-traditional' in the first report of July 2013. In the second report of the same month, they were classified as 'traditional/non-traditional depending on collateral management'.

- Derivatives for hedging were classified as 'traditional' in 2011 and not mentioned thereafter.

- Derivatives for investment purposes were classified as 'semi-traditional' in 2011 , as 'non-traditional' in the first report of July 2013 and not mentioned thereafter.

Table 2. Main items of 'non-traditional, non-insurance activities' provided by regulators

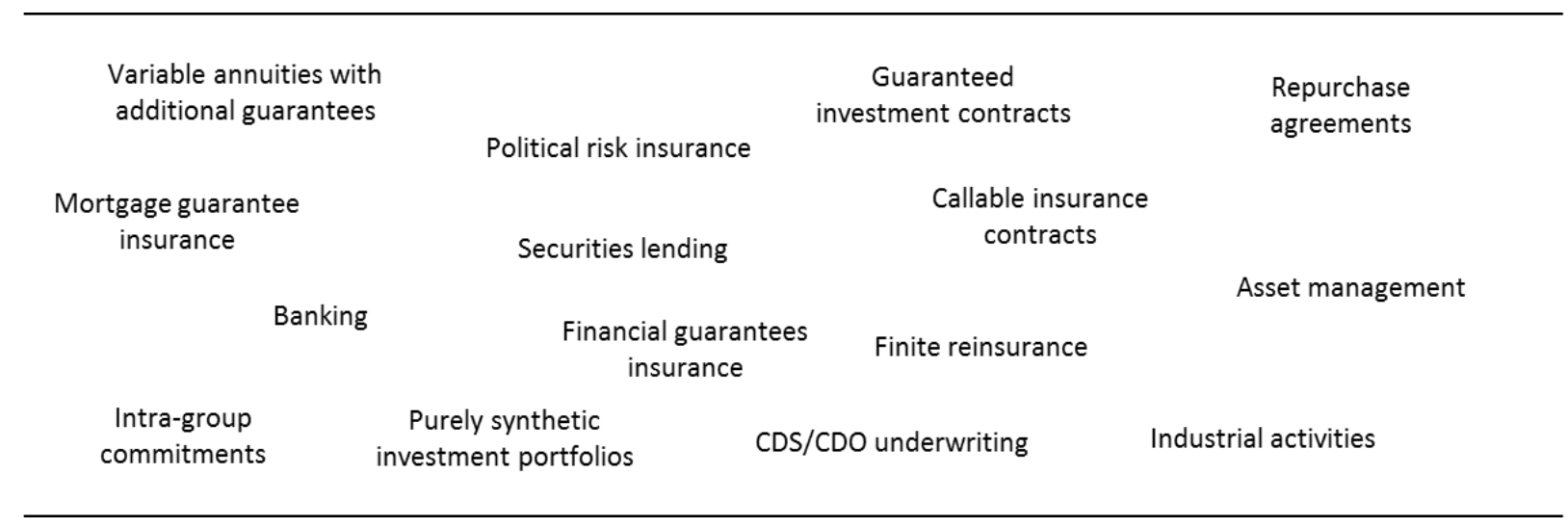

Source: See Annex Table 1.

Why is it so difficult to establish these desired categories of NTNI activities?

The first reason is that the categorisation poses the wrong question: drawing a line between 'traditional' and 'non-traditional' activities is not meaningful. There is no such thing as 'traditional' insurance, as products and risk management tools have developed gradually over decades if not centuries, in line with changing economic needs, financial market development and overall innovation. Such innovation, too, has not occurred at a specific point in time but has been stretched over the long term. Moreover, several issues that appear modern, such as derivatives, are centuries old. The problem of distinguishing 'traditional' and 'non-traditional' activities is not confined to insurance. Can one distinguish between 'traditional' accounting and 'non-traditional' accounting, between 'traditional' and 'non-traditional' banking or between 'traditional' and 'non-traditional' manufacturing, just to take three examples? 
The second reason why regulators have difficulties in classification is that they mix items of fundamentally different function and they look at these items individually, whereas several of them are actually linked. The most obvious example are derivatives, which are a longstanding tools in insurance and finance. But insurance companies mostly use them to hedge exposures and to comply with advanced regulation, such as Solvency II, that focuses on the economic concept of risk that cannot be managed without the use of derivatives. Hence, derivatives are not an end by themselves but a means to an end. The same is true for repos; repos are not a stand-alone activity towards policyholders but a management tool that is used in virtually all financial institutions.

The better way to categorise activities is to ask about their purpose, and start from the insurance contracts themselves. This is done in the subsequent section.

\section{b. A systematic classification based on a business model approach}

An actual business perspective suggests the following structure.

Insurance activities

1. Products. Insurance activities begin with the authorisation of certain insurance contracts or product categories by the regulators. Therefore, products are the starting point of insurance activities, and indeed several items of the regulators' lists refer to insurance products, such as products with guarantees.

Insurance-related activities

2. Product management tools. Subsequently, insurance companies, whose function is to manage these products and especially the risk they entail, may use certain tools to do so. Typically, derivatives fall into this category - and even more so as their use is explicitly recommended by advanced prudential frameworks such as Solvency II. ${ }^{29}$ Derivatives are the prime tool to manage risks arising from certain products, especially from very long-term exposures, guaranteed products and variable annuities.

3. Balance sheet management tools. The various insurance products - property and casualty business as well as life insurance and protection - establish a balance sheet that needs to be managed in terms of duration and liquidity profile. Balance sheet management is not product-specific but refers to the management of the balance sheet as a whole. Several activities on the regulators' list fall into this category, such as repos or securities lending.

4. Investment tools. Finally, insurance companies, which are large-scale investors with the challenge of finding appropriate investments over a long horizon, may use certain financial tools in this context. For reasons explained below, CDS contracts may be used in this context.

\footnotetext{
${ }^{29}$ By no means are derivatives only associated with variable annuity products. Even straightforward guarantee products such as German life insurance products require under Solvency II the use of derivatives if such products are to be adequately managed. The reasons is that some of the guarantees stretch out for 30 years or more and cannot be covered with regular financial investment tools; derivative products are needed to cover possible risks beyond that horizon.
} 


\section{Non-insurance activities}

5. The remaining activities are non-insurance activities. Insurance groups, as many industrial and financial groups, may include business units that are not part of their core activities but that have a role in the group because they engage in a complementary business, or because of historical reasons, such as arising from mergers and acquisitions. Such activities may include banking, asset management, industrial activities and also purely financial activities not linked to insurance business.

Table 3 - Classification of activities labelled 'NTNI' according to their function

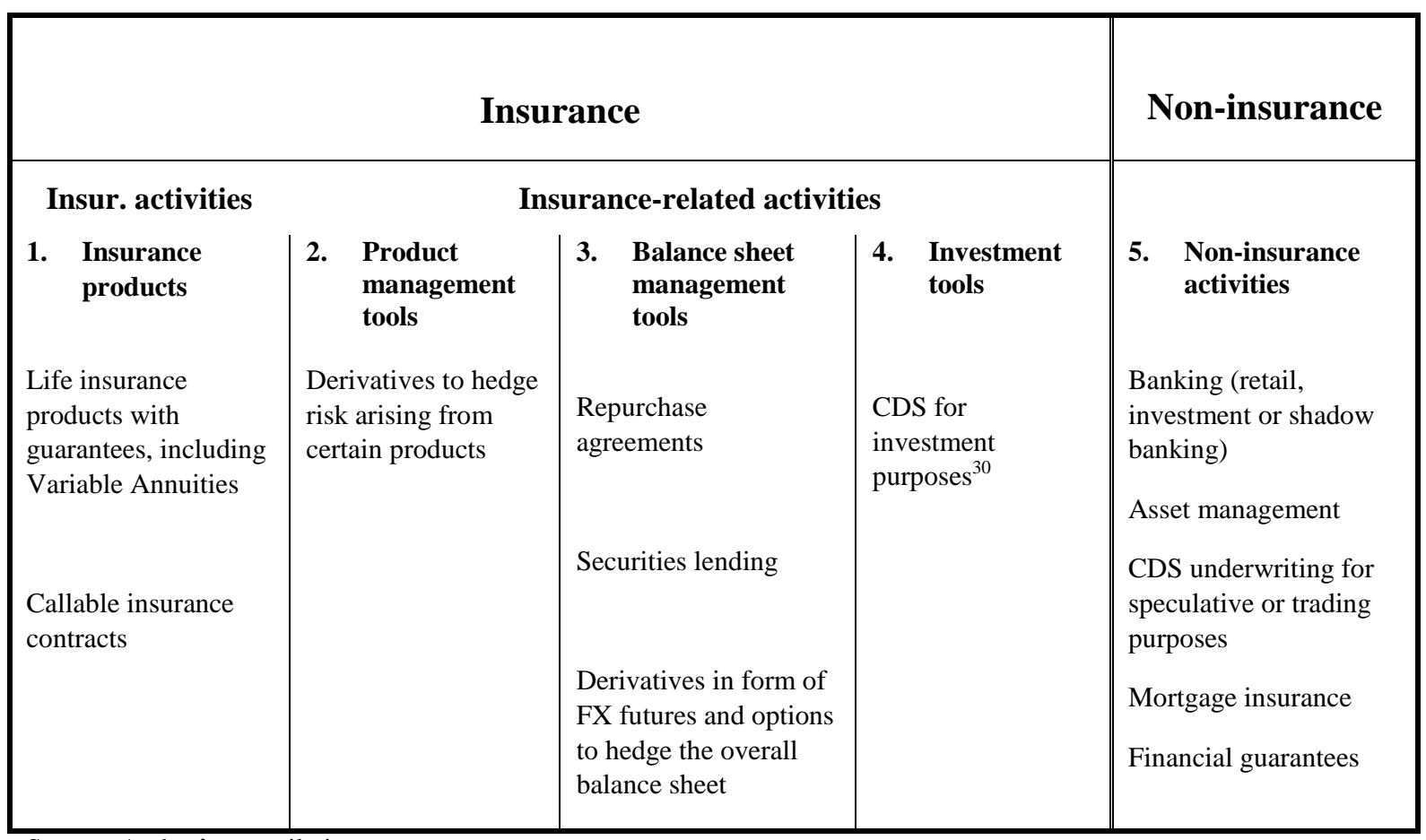

Source: Author's compilation.

\section{c. Regulation based on a systematic classification of activities}

What does the above classification mean for regulation, especially with regard to potential systemic risk?

First, such a functional categorisation makes it possible to set the first focus on the real primary sources of risk: the operation of non-insurance activities including banking-like activities, which were defined by the FSB as activities 'with the potential to create immediate liquidity stresses, due to maturity transformation combined with leverage' (FSB, 2012).

\footnotetext{
${ }^{30}$ Using derivatives for the generation of synthetic assets is simply a way to generate specific investment risk and return profiles. Holding treasuries and writing a CDS is for example an equivalent to holding a corporate bond. Such usage is part of an insurance company's normal investment activities as long as the face amount of the derivatives does not exceed the face amount of the respective risk-free assets on the insurance company's books.
} 
Here, capital surcharges, just as in the area of banking, might be a measure of last resort. The reason is that leverage usually implies raising debt on the market and/or funding activities out of debt creation. For such activities that are funded short-term on financial markets, capital is useful because it helps to ensure funding access and a positive rating. Moreover, this classification largely corresponds to the activities that proved systemically relevant during the crisis with the examples of AIG Financial Products and the financial guaranty firms such as AMBAC and MBIA (also known as monoline insurers) whose business model was not sustainable because the risks they covered were systematic and entirely correlated with the economic and financial cycle, therefore being insurance only in name.

Second, such a categorisation helps to provide a better understanding of the functional chain in the insurance business model. Regulation and supervision should be take account of the purpose of business activities: if insurance companies use derivatives, securities lending or repos, why is this so? Such an approach helps trace back the use of tools to the underlying purpose. If the purpose is to hedge, the justification is different from a situation where the purpose would be to invest and generate investment returns. In the case of hedging, exposures are reduced, and if such exposures are collateralised, meaning that exposures can be moved seamlessly in case of counterparty default, the systemic risk is actually minimised. Hence, such use of collateralised derivatives creates neither firm-to-system risks nor system-to-firm risks. This is a crucial point for systemic regulation.

Such a functional approach can help regulatory action at every point of the chain, starting with the design of insurance products. Specifically, it allows regulators to work on activities along the chain these activities are actually pursued in the insurance sector, rather than treating certain activities separately out of context.

The regulatory control steps on insurance activities would then be as follows:

1. Product design. Regulators or supervisors may want to take views on products they deem to be too complex or detrimental to consumers or the stability of the financial system. This does not imply product approval, which was abolished in the EU in 1994, but could be guidelines on certain products.

2. For given products, how should they be managed? Some insurance products will entail guarantees that expose the company to financial risks. It may hedge its risk through derivatives. Derivatives however create credit or counterparty risk. The company may collateralise its hedges to reduce these risks so that in case of counterparty default, it can move its exposures to another counterparty. Collateralising however creates liquidity risk that also needs to be managed but that is relatively easier for insurance companies to manage as they are generally liquidity-rich. At the end, risk management is about finding the best combination of financial, credit and liquidity risk. There is no obvious answer which one to reduce most, and effective supervision should aim at understanding this trade-off.

Guidance on risk management can help address this trade-off, and limits or quantitative thresholds would also be a possibility, which is not unknown in systemic risk regulation. The US Financial Stability Oversight Council has established that financial institutions will be further analysed if they have $\$ 30$ billion in gross notional CDS, $\$ 3.5$ billion in derivatives or $\$ 20$ billion in total debt outstanding. 
3. What tools are permissible for balance sheet management and to which extent and in which modalities shall they be used? For example, how should the benefits of securities lending by large insurance companies for financial market liquidity and the benefits of return be balanced with possible systemic risk due to interlinkages; should there be limits or specific guidance on the use of such tools, for example, as concerns the investment of proceeds?

4. What tools are permissible for investment purposes and how shall they be used? For example, in some less liquid markets such as the Japanese corporate debt market, exposure to corporate risk can only be obtained indirectly, through the purchases of government bonds and the sale of corporate CDS. This is fundamentally different than selling naked CDS in massive amounts as done by AIG. Nevertheless, regulators may want to review such activities and give guidance. They could also control interconnectedness; for example, by limiting large holding of bank bonds by insurers.

Such a step-by-step approach would allow regulators to ensure that possible systemic risk is taken commensurate with the individual or collective benefit of the underlying activity. It would be more effective than imposing further capital surcharges on some of these activities. As has been argued elsewhere (Thimann, 2014), capital has a different role in insurance compared with banking, and capital surcharges in insurance are not the instrument for controlling possible systemic risk. It has also been pointed out that capital is a very crude measure, which is not effective when regulatory and supervisory discretion is required to control risk (Tarullo, 2008). Finally, capital surcharges would not be able to capture the likely non-linear relationship between systemic risk and underlying activities.

\section{Conclusion}

Global financial regulators face a trade-off between uniformity and stability. The main initiatives of recent financial regulation have surely strengthened substantially the prudential regimes for institutions in all sectors. But they contain a number of elements of resemblance across sectors: in general, regulations have different treatments for short-term versus longterm exposure and risks, and different treatments for government debt compared with private debt and for private debt compared with equity and alternative forms of investment.

Such differentiation lies in the nature of things but it is a question to which degree the differentiation is fleshed out. At present, there is a clear focus across all sectors on the short term, the public sector and debt versus other instruments. Accounting standards and markingto-market practices have contributed to this as well as regulation. Insurance companies in Europe have reduced their equity holdings massively over the past decade because the capital charges for equity have become increasingly unfavourable and IFRS accounting standards have tightened asset impairment rules.

Uniformity at any point in time implies similar asset holdings; uniformity over time implies similar investment and disinvestment patterns. The former is a problem for credit provision to the real economy; the latter is a problem for procyclicality, which is a key ingredient of systemic risk. Even if institutions and sector are individually stable, uniform behaviour over time can cause systemic instability. 
The stability and proper functioning of financial markets require diversity. Such diversity is captured in different balance sheet structures, different investment horizons and different investment and disinvestment behaviour over the financial cycle. Only if different institutions and sectors can maintain different balance sheet structures and time horizons and are not measured by accounting, regulation and supervisory frameworks over the same horizon can they collectively contribute to stability.

This is why the activity-based approach towards which regulators have embarked for insurance is the right one. It is the approach that will be most effective for controlling systemic risk, for safeguarding sectoral specificity and for preventing another AIG debacle caused by a company over-reaching in other sectors.

To achieve systemic stability, the first principle for insurance regulation is to be firm on the frontier with non-insurance activities unrelated to the insurance business itself. For such an approach, it is essential to consider the key distinctions between insurance and finance.

The second principle for insurance is to start from the insurance activities proper - that is, insurance contracts and products - and to recognise that certain activities - derivatives in particular - are related to them. It is not possible properly to manage insurance risks and an insurance balance sheet without resort to standard financial tools. It would be neither justified nor appropriate for capital surcharges to discourage such tools or to raise their costs.

Guidance, thresholds and possible limits would be much more appropriate instruments for controlling systemic risk. Such an approach would allow regulators to determine which products should be accepted as insurance products, how such products shall be managed, how balance sheets can be managed and which tools should be available for investment.

An activity-based approach to regulation and supervision that is firm on the delineation of insurance from pure finance would also help to preserve diversity across sectors and allow the insurance sector to play its role and contribute to overall stability in the financial system.

\section{References}

Baranoff, Etti (2012): “An Analysis of the AIG Case: Understanding Systemic Risk and Its Relation to Insurance”, Journal of Insurance Regulation, Vol. 31, pp. 243-270.

BIS - Bank for International Settlements (2014): “Buoyant yet fragile?", Quarterly Review, 7 December 2014.

Chance Don M. (1995): “A Chronology of Derivatives”, Derivatives Quarterly 2, Winter 1995, pp. $53-60$

Evans, Robert (1987): “The Early History of Fire Insurance, Journal of Legal History, Vol. 8, Issue 1.

European Commission (2012): "Consultation on A Possible Recovery And Resolution Framework For Financial Institutions Other Than Banks", Directorate General Internal Market and Services

Fama, Eugène (1965): “The Behavior of Stock-Market Prices”, Journal of Business, vol. 38, pp. 34105. 
FCIC - Financial Crisis Inquiry Commission (2011): The Financial Crisis Inquiry Report, 27-1-2011.

Federal Reserve Bulletin (2014): "Changes in U.S. Family Finances: Evidence from the Survey of Consumer Finances", Board's Division of Research and Statistics, September, Vol. 100, No 4

FSB - Financial Stability Board (2012): "Strengthening Oversight and Regulation of Shadow Banking: An Integrated Overview of Policy Recommendations", 18 November 2012.

FSOC - Financial Stability Oversight Council (2012): “Authority to Require Supervision of Certain Nonbank Financial Companies", Federal Register, Vol. 77, Rules and Regulation, 11 April 2012.

Geneva Association (2010): "Systemic Risk in Insurance, An analysis of insurance and financial stability", Special Report of the Geneva Association Systemic Risk Working Group, March

Henderson, M. Todd (2009): "Credit Derivatives Are Not Insurance", University of Chicago Law \& Economics, Olin Working Paper No. 476, 22 July 2009.

Holdsworth, W.S. (1917): "The Early History of the Contract of Insurance”, Columbia Law Review, Vol. 17, No. 2, pp. 85-113.

IAIS - International Association of Insurance Supervisors (2011): Insurance and Financial Stability: Report, 15 November 2011.

IAIS - International Association of Insurance Supervisors (2012): Reinsurance and Financial Stability: Policy Paper, 19 July 2012.

IAIS - International Association of Insurance Supervisors (2013): Global Systemically Important Insurers: Initial Assessment Methodology, 18 July 2013.

IAIS - International Association of Insurance Supervisors (2014): Basic Capital Requirements for Global Systemically Important Insurers, 23 October 2014.

Knight, Frank H. (1921): Risk, Uncertainty and Profit. Hart, Schaffner, and Marx Prize Essays, no. 31. Boston and New York: Houghton Mifflin.

Leland, H. and Rubinstein, M. (1976): "The Evolution of Potfolio Insurance", in Portfolio Insurance: A guide to Dynamic Hedging by Luskin, D.L, Wiley.

Leland, Hayne E. (1980): "Who should buy Portfolio Insurance", Journal of Finance, Vol. 35, pp. 581-594.

Levine, Ross (1996): "Financial development and economic growth: views and agenda", Policy Research Working Paper Series 1678, The World Bank.

Lintner, John (1965): "The Valuation of Risk Assets and the Selection of Risky Investments in Stock Portfolios and Capital Budgets", Review of Economics and Statistics, Vol. 47, No. 1, pp. 1337.

Lo, A. and MacKinlay, C. (1999): A Non-Random Walk Down Wall Street. Princeton University Press.

Malkiel, Burton G. (1973): A Random Walk Down Wall Street. The Time-tested Strategy for Successful Investing. W.W. Norton.

Markowitz, Harry M. (1952): "Portfolio Selection”, The Journal of Finance, vol. 7, pp. 77-91.

Markowitz, Harry M. (1957): “A Simplex Method for the Portfolio Selection Problem”, Cowles Foundation Discussion Papers 27, Cowles Foundation, Yale University.

Merna, Tony and F. Al-Thani (2008): Corporate Risk Management, 2nd Edition, April

Moss, D. and E. Kintgen (2010): "The Dojima Rice Market and the Origins of Futures Trading", Harvard Business School, 10 November 2010.

OECD - Organisation for Economic Co-operation and Development (1995): Recommendation of the Council on Improving the Quality of Government Regulation, 9 March 1995. 
Peirce Hester (2014): "Securities Lending and the Untold Story in the Collapse of AIG", George Mason University Mercatus Center Working Paper No. 14-12, May

Peltzman, Sam (1976): “Toward a More General Theory of Regulation", Journal of Law and Economics, University of Chicago Press, vol. 19(2), pp. 211-40, August.

Sharpe, W.F. (1963): “A Simplified Model for Portfolio Analysis”, Management Science, INFORMS, vol. 9(2), pp. 277-293.

Sharpe, W.F. (1964): "Capital Asset Prices: A Theory of Market Equilibrium under Conditions of Risk", Journal of Finance, vol. 19, No. 3, pp. 425-442.

Sorkin, Andrew R. (2009): “The Case for Saving AIG, by AIG”, New York Times, 2 March 2009.

Spindt, Paul (1985): "Money Is What Money Does: Monetary Aggregation and the Equation of Exchange", Journal of Political Economy, Vol. 93, No. 1, pp. 175-204

Stigler, George J. (1971): “The Theory of Economic Regulation”, Bell Journal of Economics, RAND Corporation, vol. 2(1), pp. 3-21, Spring.

Tarullo, D. K. (2008): Banking on Basel: The Future of International Financial Regulation. Peterson Institute for International Economics Washington, DC, August.

Thimann, Christian (2014): "How Insurers Differ from Banks: A Primer in Systemic Regulation", LSE Systemic Risk Centre Special Paper 3, July.

Trennery, Charles F. (1926): The Origin and Early History of Insurance : Including the Contract of Bottomry, P.S. King \& Son, ltd, London.

Vaughan, Emmett J. (1997): Risk Management. University of Iowa.

World Economic Forum (2014): Global Risks 2014, Ninth Edition, 16 January 2014. 
Annex Table A. Classifications of 'traditional' and 'non-traditional' insurance activities compiled from various official reports arranged by purpose

\begin{tabular}{|c|c|c|c|c|c|c|}
\hline & Definition & 莺 & $\begin{array}{l}\text { Insurance } \\
\text { Fin. Stability } \\
\text { Report (IAIS, } \\
\text { Nov. 2011) }\end{array}$ & $\begin{array}{l}\text { Assessment } \\
\text { Methodology } \\
\text { (IAIS, July } \\
\text { 2013) }^{32}\end{array}$ & $\begin{array}{c}\text { Policy } \\
\text { Measures } \\
\text { for GSII } \\
\text { (IAIS, } \\
\text { July } \\
2013)^{33}\end{array}$ & $\begin{array}{c}\text { BCR } \\
\text { formula } \\
\text { (IAIS, } \\
\text { Sept. } \\
\text { 2014) }\end{array}$ \\
\hline \multicolumn{2}{|l|}{ Products } & & \multicolumn{4}{|c|}{ Classification provided } \\
\hline $\begin{array}{l}\text { Variable } \\
\text { annuities } \\
\text { (VAs) with } \\
\text { additional } \\
\text { guarantees }\end{array}$ & $\begin{array}{l}\text { VAs with living benefits or death } \\
\text { benefits }\end{array}$ & $* * *$ & $\begin{array}{l}\text { Semi- } \\
\text { Traditional }\end{array}$ & NTNI & NT & NT \\
\hline $\begin{array}{l}\text { Callable } \\
\text { insurance } \\
\text { contracts }\end{array}$ & $\begin{array}{l}\text { Products that can be surrendered in } \\
\text { short delay and/or without penalties }\end{array}$ & $* * *$ & $\varnothing$ & NTNI & NT & $\varnothing$ \\
\hline $\begin{array}{l}\text { Guaranteed } \\
\text { investment } \\
\text { contracts }\end{array}$ & $\begin{array}{l}\text { The insurance company provides a } \\
\text { guaranteed rate of return to the } \\
\text { purchaser in exchange for keeping a } \\
\text { deposit for a fixed period of time. }\end{array}$ & $*$ & & & & NT \\
\hline $\begin{array}{l}\text { Mortgage } \\
\text { guarantee } \\
\text { insurance }\end{array}$ & $\begin{array}{l}\text { Indemnity to credit providers for } \\
\text { losses due to the failure of a borrower } \\
\text { to repay a loan secured by a mortgage } \\
\text { over property }\end{array}$ & $*$ & $\begin{array}{l}\text { Semi- } \\
\text { Traditional }\end{array}$ & NTNI & NT & NT \\
\hline $\begin{array}{l}\text { Commercial } \\
\text { credit } \\
\text { insurance } \\
\text { including } \\
\text { suretyship }\end{array}$ & $\begin{array}{l}\text { Indemnity for financial losses due to } \\
\text { the failure of a commercial entity to } \\
\text { repay outstanding credit contracts or } \\
\text { failure to perform contracted services } \\
\text { or deliver contracted products other } \\
\text { than short-term trade credit and } \\
\text { suretyship insurance }\end{array}$ & & $\begin{array}{l}\text { Semi- } \\
\text { Traditional }\end{array}$ & NTNI & NT & NT \\
\hline $\begin{array}{l}\text { Financial } \\
\text { guarantees } \\
\text { insurance }\end{array}$ & $\begin{array}{l}\text { An insurance company guarantees } \\
\text { scheduled payments of interest and } \\
\text { principal on a bond or other security } \\
\text { in the event of a payment default by } \\
\text { the issuer of the bond or security }\end{array}$ & & NT & NTNI & NT & NT \\
\hline $\begin{array}{l}\text { Political risk } \\
\text { insurance }\end{array}$ & $\begin{array}{l}\text { A type of insurance that can be taken } \\
\text { out by businesses against the risk that } \\
\text { revolution or other political conditions } \\
\text { will result in a loss }\end{array}$ & & $\varnothing$ & $\varnothing$ & $\varnothing$ & NT \\
\hline \multicolumn{7}{|c|}{ Product management tools } \\
\hline $\begin{array}{l}\text { Derivatives } \\
\text { for hedging } \\
\text { or replication } \\
\text { purposes }\end{array}$ & $\begin{array}{l}\text { Derivatives not used for speculating } \\
\text { purposes }\end{array}$ & $* * *$ & Traditional & $\varnothing$ & $\varnothing$ & $\varnothing$ \\
\hline
\end{tabular}

\footnotetext{
${ }^{31}$ IAIS, Insurance Financial Stability Report (November 2011)

32 IAIS, Global Systemically Important Insurers: Initial Assessment methodology (July 2013)

${ }^{33}$ IAIS, Global Systemically Important Insurers: Policy measures (July 2013)

${ }^{34}$ IAIS, Consultation on Basic Capital Requirement (July 2014)
} 


\begin{tabular}{|c|c|c|c|c|c|c|}
\hline & Definition & 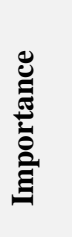 & $\begin{array}{l}\text { Insurance } \\
\text { Fin. Stability } \\
\text { Report (IAIS, } \\
\text { Nov. 2011) }\end{array}$ & $\begin{array}{l}\text { Assessment } \\
\text { Methodology } \\
\text { (IAIS, July } \\
\text { 2013) }^{32}\end{array}$ & $\begin{array}{c}\text { Policy } \\
\text { Measures } \\
\text { for GSII } \\
\text { (IAIS, } \\
\text { July } \\
\text { 2013) }\end{array}$ & $\begin{array}{c}\text { BCR } \\
\text { formula } \\
\text { (IAIS, } \\
\text { Sept. } \\
\text { 2014) }\end{array}$ \\
\hline \multicolumn{7}{|c|}{ Balance sheet management tools } \\
\hline $\begin{array}{l}\text { Repurchase } \\
\text { agreements }\end{array}$ & $\begin{array}{l}\text { The sale of securities together with an } \\
\text { agreement for the seller to buy back } \\
\text { the securities at a later date }\end{array}$ & $* * *$ & & NTNI & $\begin{array}{c}\text { Tradit. if } \\
\text { cash } \\
\text { collateral } \\
\text { invested } \\
\text { in liquid } \\
\text { assets. NT } \\
\text { if not }\end{array}$ & $\varnothing$ \\
\hline $\begin{array}{l}\text { Securities } \\
\text { lending }\end{array}$ & $\begin{array}{l}\text { Securities-lending transactions can be } \\
\text { initiated because a borrower needs } \\
\text { particular securities or because the } \\
\text { lender needs cash. In such } \\
\text { transactions, the borrower borrows } \\
\text { securities and collateralises them with } \\
\text { cash to secure the loan, in the US } \\
\text { typically } 102 \% \text { of the value of the } \\
\text { securities borrowed }\end{array}$ & $* * *$ & Traditional & NTNI & $\begin{array}{c}\text { Tradit. if } \\
\text { cash } \\
\text { collateral } \\
\text { invested } \\
\text { in liquid } \\
\text { assets. NT } \\
\text { if not }\end{array}$ & $\varnothing$ \\
\hline $\begin{array}{l}\text { Cascades of } \\
\text { repos \& } \\
\text { Securities } \\
\text { lending }\end{array}$ & & & NT & NTNI & $\emptyset$ & $\varnothing$ \\
\hline $\begin{array}{l}\text { Alternative } \\
\text { risk transfer } \\
\text { (ART), } \\
\text { including } \\
\text { insurance } \\
\text { linked } \\
\text { securities } \\
\text { (ILS) }\end{array}$ & $\begin{array}{l}\text { The use of techniques other than } \\
\text { traditional insurance and reinsurance } \\
\text { to provide risk coverage (for example, } \\
\text { securitisation of the contracts) }\end{array}$ & & NT & & $\begin{array}{l}\text { ILS with } \\
\text { financial } \\
\text { risk are } \\
\text { NT } \\
\text { If not, } \\
\text { traditional }\end{array}$ & $\varnothing$ \\
\hline $\begin{array}{l}\text { Finite } \\
\text { reinsurance }\end{array}$ & $\begin{array}{l}\text { A type of reinsurance that transfers } \\
\text { over only a finite or limited amount of } \\
\text { risk }\end{array}$ & & NT & $\varnothing$ & $\varnothing$ & $\varnothing$ \\
\hline $\begin{array}{l}\text { Intra-group } \\
\text { commitments }\end{array}$ & $\begin{array}{l}\text { Commitments between insurance } \\
\text { entities and non-insurance entities } \\
\text { within a group }\end{array}$ & & & NTNI & & $\varnothing$ \\
\hline \multicolumn{7}{|l|}{$\begin{array}{l}\text { Investment } \\
\text { tools }\end{array}$} \\
\hline $\begin{array}{l}\text { Derivatives } \\
\text { used for } \\
\text { investment } \\
\text { purposes }\end{array}$ & & & $\begin{array}{c}\text { Semi } \\
\text { traditional }\end{array}$ & NTNI & & $\varnothing$ \\
\hline $\begin{array}{l}\text { Purely } \\
\text { synthetic } \\
\text { investment } \\
\text { portfolios }\end{array}$ & $\begin{array}{l}\text { A synthetic investment simulates the } \\
\text { return of an actual investment, but the } \\
\text { return is actually created by using a } \\
\text { combination of financial instruments }\end{array}$ & & NT & & & $\emptyset$ \\
\hline
\end{tabular}




\begin{tabular}{|c|c|c|c|c|c|c|}
\hline & Definition & 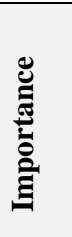 & $\begin{array}{c}\text { Insurance } \\
\text { Fin. Stability } \\
\text { Report (IAIS, } \\
\text { Nov. 2011) }\end{array}$ & $\begin{array}{c}\text { Assessment } \\
\text { Methodology } \\
\text { (IAIS, July } \\
\text { 2013) }^{\mathbf{3 2}}\end{array}$ & $\begin{array}{c}\text { Policy } \\
\text { Measures } \\
\text { for GSII } \\
\text { (IAIS, } \\
\text { July } \\
\text { 2013) }\end{array}$ & $\begin{array}{c}\text { BCR } \\
\text { formula } \\
\text { (IAIS, } \\
\text { Sept. } \\
\text { 2014) }\end{array}$ \\
\hline $\begin{array}{l}\text { CDS/CDO } \\
\text { underwriting }\end{array}$ & & & NI & NTNI & & $\varnothing$ \\
\hline $\begin{array}{l}\text { Capital } \\
\text { market } \\
\text { business }\end{array}$ & & & NI & NI & & \\
\hline Banking & $\begin{array}{l}\text { Banking subsidiary of an insurance } \\
\text { company }\end{array}$ & $* *$ & NI & NI & & NI \\
\hline $\begin{array}{l}\text { Third-party } \\
\text { asset } \\
\text { management }\end{array}$ & $\begin{array}{l}\text { Asset management subsidiary of an } \\
\text { insurance company }\end{array}$ & $* * *$ & NI & NI & & NI \\
\hline $\begin{array}{l}\text { Industrial } \\
\text { activities }\end{array}$ & & $*$ & NI & & & NI \\
\hline
\end{tabular}

